\author{
Драгана МРШЕВИЋ-РАДОВИЋ \\ Универзитет у Београду \\ Филолошки факултет
}

\title{
ОБРАТИ (ЗЕЛЕН) БОСТАН
}

Једна таџичка пословица каже: „Боље је да откинеш главу вртлару него незрелу дињу" (Vox populi, 382).

А она је врло блиска српском изразу обрати (зелен) бостан. Придев зелен употребљен је у значењу „незрео”, а бостан је турцизам персијског порекла и означавао је „врт за диње и лубенице”, потом, по закону синегдохе, „диње и лубенице уопште”. Према Скоку, ову реч имају и други балкански језици - бугарски, албански, цинцарски, румунски, новогрчки, а у бугарском се употребљава у саставу израза обрах бостана и обрах си зелен бостаня. Међу Вуковим пословицама забележена је у контексту: Како ради, обраће зелен бостан, тј. пропашће. Према једном тумачењу, то је поука настала из праксе: баштован који обере зелен бостан не може другоме да га прода и због тога губи новац, тј. материјално пропада. Занимљиво је да се на сличан начин тумачи значење фразеологизам у бугарском језику - „пре времена потрошити, изгубити свој доходак, приход”, „сам себи посао покварити" (Фразеологичен речник на българския език, 2, 11).

У српском језику, према Речнику САНУ, фразеологизам обрати (зелен) бостан примењује се за онога који за неки свој поступак очекује неке непријатне последице или казну (уп. Још само да положим суду кауцију, па је твој Перо обрао бостан. М. Глишић). Ако ови завладају, обрасмо ми зелен бостан. Д. Ћосић). О каквим је последицама реч не експлицира се, али свакако не мисли се или бар не само на материјалну пропаст.

Зато ћемо скренути пажњу на једну важну чињеницу: у „Казнитељном законику за Књажество Србију" из 1864. године налазимо да се према једном члану законика предвиђа: „Да се казни новчано од три цванцика до три талира, или затвором од једног до три дана, или бојем [тј. батинама] са десет удараца ко незрело воће или бостан продаје". (Још ће се притом 
ово воће или бостан одузети, а бостанџија је дужан да купцу новац узет за бостан врати.) (Зак. 6, 143).

Зашто је тако строго забрањено било продавати зелен бостан и зашто се једним чланом баш Санитетског законика (из 1919. године, на пример), забрањује продаја незрелог воћа?

Одговор лежи у опасности да се могуће стомачне болести у лошим епидемиолошким условима могу лако да претворе у епидемију, а страх је разумљиво изузетно велики када помислимо да је у прошлости превентива била и још много значајнија него данас.

И данас обрати (зелен) бостан значи „зло проћи”, баш као што је имао очекивати и несавесни бостанџија, којем је за учињени прекршај следила заслужена казна.

\section{ЛИТЕРАТУРА}

Vox populi, (zlatnja knjiga poslovica svijeta), (prir. Tomislav Radić), Zagreb, Globus, 1989.

Вук Стеф. Караџић, Српске народне пословище, Сабрана дела Вука Караџића, књига девета, Београд, Просвета, 1965.

Казнителный законикъ за Княжество Србію, Београд, 1864.

P. Skok, Etimologijski rječnik hrvatskoga ili srpskoga jezika, Zagreb, Jugoslovenska akademija znanosti i umjetnosti, knjiga prva, 1971.

Речник српскохрватског књижевног и народног језика, Институт за српски језик, Српска академија наука и уметности, књига 2, Београд, 1971.

Фразеогичен речник на българския език (К. Ничева, С. Спасова-Михайлова, Кр. Чолакова), I (1974); II (1995), София. 


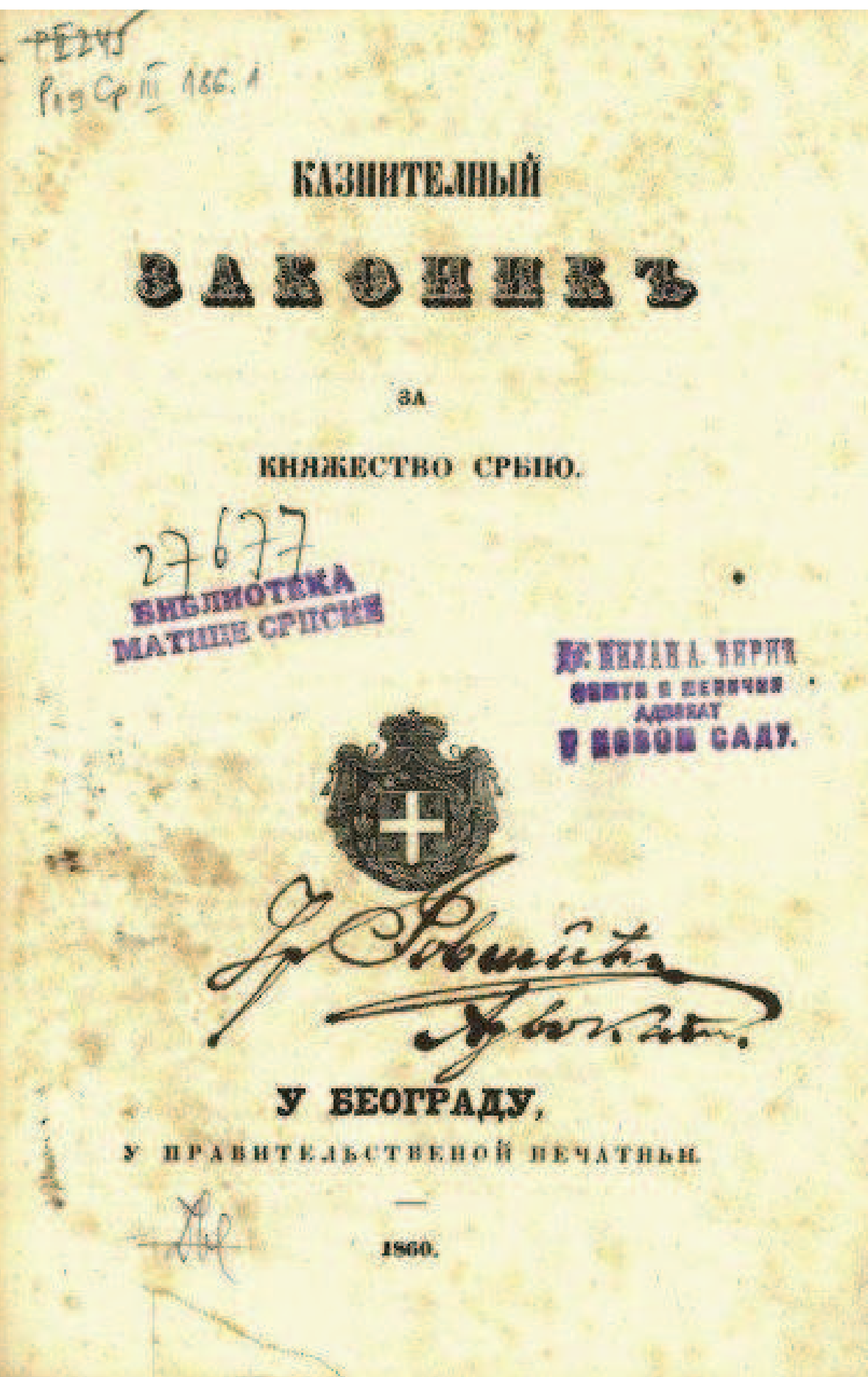

